\title{
Assessing Soil Salinity Risk in the RUT Irrigation District, Colombia
}

\author{
Evaluación del riesgo de salinización de los suelos \\ del distrito de riego RUT Colombia
}

\author{
Avaliação do risco de salinização dos solos do distrito \\ de irrigação RUT Colômbia
}

\author{
Andrés F. Echeverri-Sanchez ${ }^{1 *}$; Paola A. Angulo-Rojas ${ }^{2 *}$; Diego M. Saavedra-Corredor ${ }^{3 *}$; \\ Cristo Facundo Pérez ${ }^{4}$; Norberto Urrutia-Cobo ${ }^{5}$
}

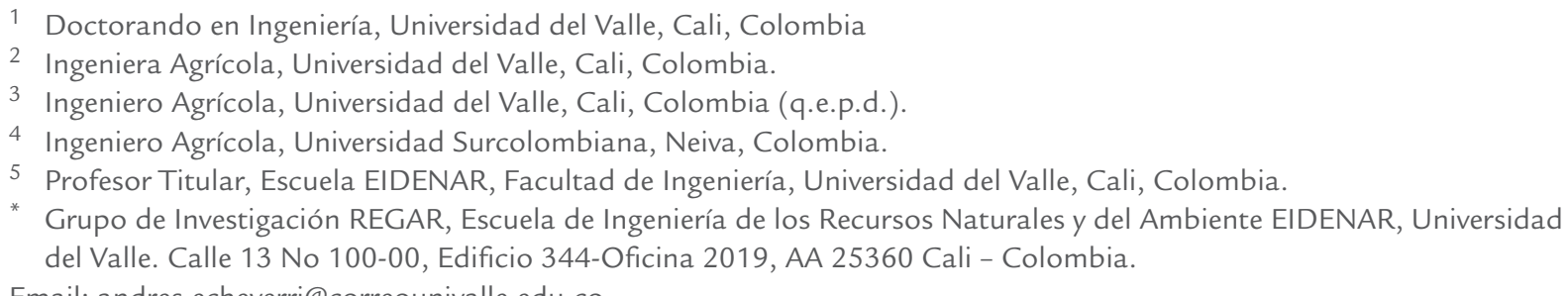

Email: andres.echeverri@correounivalle.edu.co

Recibido: 4 de abril de 2016

Aceptado: 25 de mayo de 2017

\begin{abstract}
The water resources mismanagement is a common concern in the agriculture, and this issue is boosting salinity processes in the Colombian lands. Thus, this paper aimed to assess the soil salinity risk in the RUT irrigation district for sugarcane, grape, and passion fruit by coupling SOSALRIEGO-GIS. First, sources of surface water and their influence areas were identified in the RUT irrigation district. Afterwards, inputs (water ionic constituents, electrical conductivity of rainwater, annual rainfall, crop salt tolerance, soil texture, and leaching fraction) fed in the SOSALRIEGO model, and then, the leaching requirement (LR) of each zone was computed (output) for each crop. Finally, employing GIS, LR values were arranged in categories in order to map the soil salinity risk in the RUT irrigation district for each crop and zone. The soil salinity risk fell into a medium rank for sugarcane, medium to high ranks for grape, and high to very high ranks for passion fruit. Furthermore, the soil salinity risk was higher in zones with poor irrigation water quality. Zones II and III, which canals convey domestic wastewater and drained water fell in greater salinity risk category than zone I, which bears water withdrawal from the Cauca River.
\end{abstract}

Key Words: irrigation water quality, soil salinization, SOSALRIEGO, risk management.

\section{Resumen}

La inadecuada gestión de los recursos hídricos es una preocupación común en la agricultura, y este hecho está impulsando procesos de salinización en los suelos de Colombia. Por lo tanto, este trabajo tuvo como objetivo evaluar el riesgo de salinización del suelo en el distrito de riego RUT para cultivos de caña de azúcar, uva, maracuyá integrando el modelo 
SOSALRIEGO con SIG. En primer lugar, se identificaron las fuentes hídricas y sus áreas de influencia. Posteriormente, los parámetros de entrada (composición iónica del agua, conductividad eléctrica del agua de lluvia, precipitación anual, tolerancia de cultivos a la salinidad, cultivos, textura del suelo y la eficiencia de lavado) alimentaron el modelo SOSALRIEGO y, a continuación, el Requerimiento de Lavado de sales (RL) fue calculado para cada cultivo. Por último, utilizando SIG, los valores RL se organizaron en categorías con el fin de mapear el riesgo de salinización del suelo en el distrito de riego RUT para cada cultivo en cada zona. El riesgo de salinización se clasificó como medio para caña de azúcar, medio a Alto para la uva, y alto a muy alto para maracuyá. Además, el riesgo salinización del suelo encontrado fue mayor en zonas con baja calidad del agua de riego. Las Zonas II y III, en las cuales los canales conducen aguas residuales domésticas y el agua drenada fueron calificados en categorías superiores de riesgo de salinización que la Zona I, la cual recibe agua extraída directamente del río Cauca.

Palabras Clave: calidad del agua de riego, manejo del riesgo, salinización de suelos, SOSALRIEGO.

\section{Resumo}

A inadequada gestão dos recursos hídricos é uma preocupação comum na agricultura, este fato está impulsando processos de salinização nos solos da Colômbia. Portanto, esta pesquisa objetivou avaliar o risco da salinização dos solos no distrito de irrigação RUT às culturas de cana-de-açúcar, uva e maracujá; integrando o modelo SOSALRIEGO com os Sistemas de Informações Geográficas (SIG). Em primeiro lugar, os parâmetros de entrada (composição iônica da água de irrigação, condutividade elétrica da água de precipitação, precipitação anual, tolerância das culturas à salinidade, culturas, textura do solo e eficiência de lavado de sais) alimentaram o modelo SOSALRIEGO e, seguidamente o requerimento de lavado de sais (RL) foi calculado. Finalmente, usando os SIG, os valores de RL foram categorizados com o objetivo de mapear o risco de salinização dos solos na área de estudo para cada cultura em cada zona. O risco de salinização foi classificado como Médio para a cultura da cana-de-açúcar, Médio a Elevado para a cultura da uva, e Elevado a Muito Elevado para o maracujá. Além disso, o risco de salinização foi maior nas zonas com menor qualidade da água de irrigação. As zonas II e III, cujos canais conduzem águas residuais e de drenagem foram qualificados em categorias maiores de risco do que a zona I, a qual extrai a água diretamente do Rio Cauca.

Palavras Chave: qualidade da agua de irrigação, gestão do risco, salinização de solos, SOSALRIEGO.

\section{Introduction}

For centuries, the irrigation has been one of the activities preferred by humanity for increasing soil productivity (FAO, 2007). However, this practice's mismanagement-plus low water quality-may lead soil to salinize, a slow-step phenomenon, affecting negatively both soil quality and agricultural yield, and thereby farmer's income (Fernández et al., 2011; García, 2013).

Salinity is a complex process of chemical degradation that affects the physical properties of soils, which submit to heterogeneous distribution, vary over time and space. Around the world exist over 800 million hectares of soils affected by the higher concentration of different types of salts, which means that is one of the most important problems in the agriculture. The salinity has defined as one of the main processes of soil degradation that is reaching $7.7 \%$ equivalent approximately to $87300 \mathrm{~km} 2$ of the area of Colombia. (Narváez, Combatt, y Bustamante, 2014).

A widespread approach to evaluate the soil salinity risk was proposed by the U.S Soil Laboratory (USSL staff, 1954). They assessed salinity risk based only on the electrical conductivity of irrigation water (CEw), and found then that the higher ECw values in the water the higher its soil salinity risk. Afterwards, some studies addressed natural resources risk by evaluating more than a parameter (CEw), but employing just one risk component. i.e. either the potential hazard or vulnerability (Bouksila et al., 2013;. Clermont-Dauphin et al., 2010; de Paz et al., 2004; Kanzari et al., 2012; Triantafilis et al., 2004). Moreover, some other authors have taken a step forward in determining the soil salinity risk, and they evaluated risk encompassing-without any distinction-both hazard and vulnerability components (de Paz et al., 2007; Masoudi et al., 2006; Zhou et al., 2013; Villafañe, 2011).

One of these authors (Villafañe, 2011), developed a procedure named SOSALRIEGO for diagnosing soil sodicity and salinity in Latin American by computing hazard (water quality), and vulnerability (climate and soil factors). But this approach does not map the risk (output), which may potentiate the analysis for planning and managing strategies to control the soil salinization (Peragóna et al., 2016; Bouksila et al., 2013; Mirlas, 2012; Akramkhanov et al., 2011; Juan et al., 2011a; Utset y Borroto, 2001).

The RUT (Roldanillo, Union y Toro) Irrigation District is one of the most important irrigation systems in the 
southwest of Colombia due to a strategic geographical position and favorable edaphic conditions for developing agriculture. The natural agricultural vocation of the irrigation district is for the establishment of crops of grains, fruit trees and vegetables; however, for economic, social and political reasons, 55\% of the area of the district is currently under the crop of sugarcane with a growing tendency to increase its cropping area.

The soils of the RUT Irrigation District are of alluvial origin, with textures that vary from medium to heavy, moderately deep with poor internal drainage. There are reports of salinity and / or sodicity in at least $17 \%$ of the RUT area. They are soils that require agricultural mechanization and good management of irrigation and drainage (IGAC - CVC, 2004). Therefore, this paper was aimed to assess soil salinity risk in the RUTirrigation district by using SOSALRIEGO model, and coupling it withGIS.

\section{Materials and methods}

\section{Location and description of the study area}

The RUT irrigation District is located on the direct influence area of Roldanillo, Unión y Toro municipalities, in Valle del Cauca Department (Fig. 1). It covers an area of 10200 ha, which benefits 1800 fields (1200 users).
The RUT irrigation system is basically a flood protection and irrigation/drainage project. The flood control system includes interceptor canal (parallel to west Andes foothill) and protection dike (parallel to Cauca River). The irrigation system is comprised of pumping stations (Candelaria and Tierrablanca) and primary, secondary and tertiary canals. The primary canals are interceptor, main, and canal 1.0. The drainage system consists of pumping stations (Cayetana and San Luis) and main, secondary, and tertiary canals (Urrutia, 2006).

\section{SOSALRIEGO model}

SOSALRIEGO approach (Villafañe, 2011) requires inputs such as water ionic constituents, electrical conductivity of rainwater, annual rainfall, crop salt tolerance, soil texture, and leaching fraction (LF); and as output it provides predicted salts in the irrigation water, amendment types, and leaching requirement (LR). Only LR values were used to assess the soil salinity risk, and hence, to fed in the GIS tool.

\section{Input parameters}

\section{Physicochemical characteristics of irrigation water:} 10 water samples-with replicates-were grabbed in the RUT irrigation district for each of three campaigns (September 2013, January 2014, and August 2014). Major parameters such as electrical conductivity $(\mathrm{ECW})$, cations $\left(\mathrm{Ca}^{2+}, \mathrm{Mg}^{2+}, \mathrm{Na}^{+}, \mathrm{K}^{+}\right)$and anions
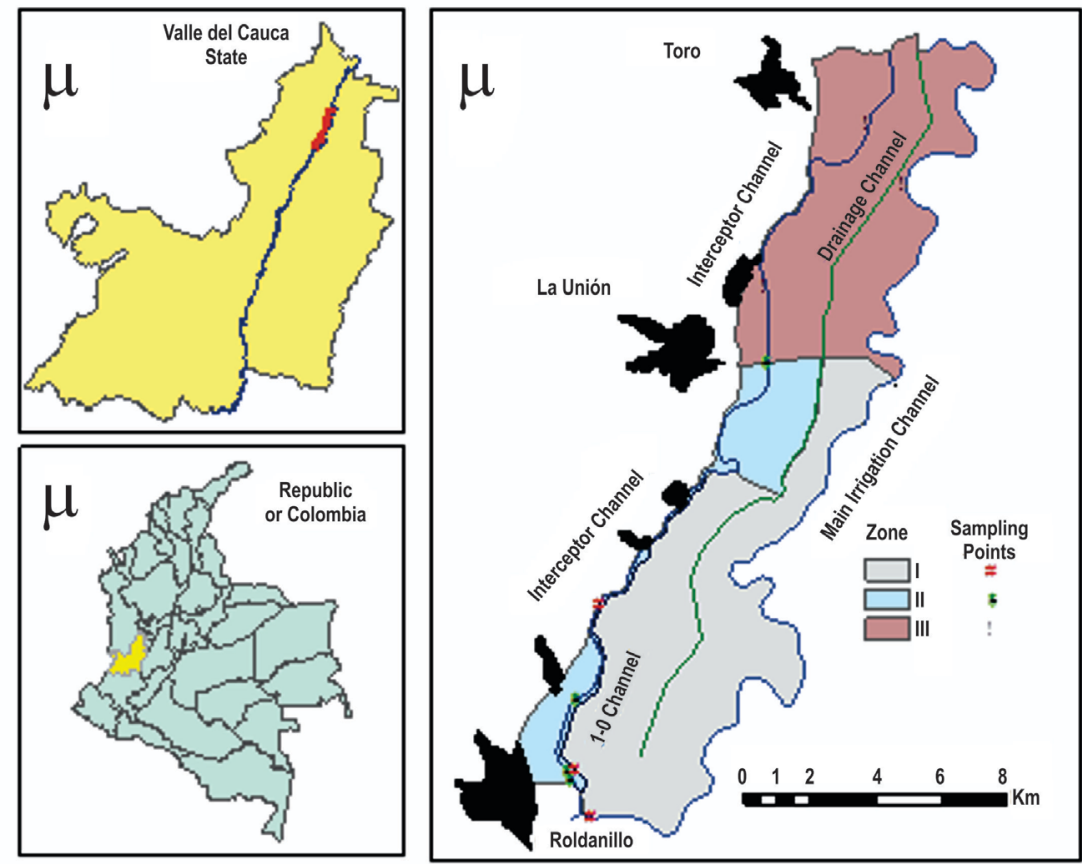

Figura 1. Location of the RUT irrigation district 
$\left(\mathrm{HCO}_{3}{ }^{-}\right.$or $\left.\mathrm{CO}_{3}{ }^{2}, \mathrm{Cl}, \mathrm{SO}_{4}{ }^{*}\right)$ were determined following standard procedures from American Public Health Association-APHA (APHA, 1999). These sampling points were distributed among three different water quality regions inside the RUT (Roldanillo, La Union y Toro) irrigation District (Table 1).

Electrical conductivity of rainwater: a $0.15 \mathrm{dS} \mathrm{m} \mathrm{m}^{-1}$ value of ECp was employed to feed in the model. This value is suggested by the SOSALRIEGO's author.

Annual rainfall: two probabilities of exceedance (P50\% and P75\%) were forecasted for annual rainfall (P). A 11-station database was analyzed by using normal distribution method. Ordinary kriging interpolation was carried out in the ArcGIS ${ }^{\circ} 10.3$ software. This interpolation method best describes the spatial relationship of rainfall, and thus has been successfully employed by other authors (Bargaoui and Chebbi, 2009; Di Piazza et al., 2011; Bostan et al., 2012). The rainfall values calculated for each scenario were: $1233.5 \mathrm{~mm}$ year $^{-1}$ and $832.7 \mathrm{~mm}_{\text {year }}{ }^{-1}$ for 50 and $75 \%$ probabilities of exceedance, respectively.

Crop salt tolerance: sugarcane, grapes and passion fruit were selected to be used in SOSALRIEGO. Their salinity tolerances are $1.7,1.5$ and $1 \mathrm{dS} \mathrm{m}^{-1}$, respectively (Ayers y Westcot, 1985). These three cultivars were chosen because they are the most representative crops in the RUT irrigation district.

Soil texture and leaching efficiency factor: Soil texture dominant in the RUT irrigation district is heavy (0.5), being clear that leaching efficiency factor will be lower in the case of heavy textures (IGAC-CVC, 2004).

\section{Statistical analysis}

The independence, normality (Shapiro-Wilk test) and homogeneity of the variances (Levene test) were not verified in LR values; hence, Kruskal-Wallis-a non- parametric test-was applied in the comparison of LR among sampling campaigns, crops, and zones. Besides, pairwise comparison was performed for validating the analysis. The analytical process was run at IBM $\mathbb{R}$ SPSS ${ }^{\circledR}$ Statistics 20 software.

\section{Risk Mapping}

The ArcGIS® 10.3. software was used for mapping LR, which represented the soil salinity risk in the RUT irrigation district. In the process, risk categories were assigned to each polygon from the influence area of each evaluated sample.

\section{Results}

\section{Irrigation water quality}

The concentration values of water quality shown in Table 2 met the suitable limits of the FAO guidelines for quality agricultural water (Ayers and Westcot, 1985). However, comparing them with an earlier study carried out in the region (CVC, 1986), we found that ion concentrations are steadily increasing in the surface water.

\section{Soil salinity risk}

RL values for each crop statistically did not differ ( $p$ value $>0.050$ ) over time (among sampling campaigns) in each zone (Table 3). Thus, the soil salinity risk for sugarcane, grape, and passion fruit were mapped using the average LR value in each zone of the RUT irrigation district under two rainfall scenarios (Figure 2).

In the first scenario (P50\%), both sugarcane and grape fell into medium soil salinity risk (LR values from 0.11 to 0.20 ); while passion fruit classed as high ( $L R$ values from 0.21 to 0.30$)$. In the second scenario (P75\%), sugarcane kept its medium soil salinity risk level; whereas

Table 1. Characteristics of Irrigation zones in the RUT irrigation district

\begin{tabular}{|c|l|c|}
\hline Zone & \multicolumn{1}{|c|}{ Features } & Sampling numbers \\
\hline I & $\begin{array}{l}\text { Water withdrawal from the Cauca River and carried through the main irrigation } \\
\text { canal and canal 1.0. There is not wastewater discharge from nearby villages. }\end{array}$ & 3 \\
\hline II & $\begin{array}{l}\text { The interceptor canal conveys water from the Cauca River mixed with } \\
\text { sewage dumped by nearby villages and municipality treatment plants. }\end{array}$ & 4 \\
\hline III & $\begin{array}{l}\text { Irrigation water is supplied by the main drain and the northern interceptor canal, which } \\
\text { transports wastewater from La Union and previous municipalities at this point. }\end{array}$ & 3 \\
\hline
\end{tabular}


Table 2. Irrigation water quality in the RUT irrigation district

\begin{tabular}{|c|c|c|c|c|c|c|c|c|c|c|}
\hline \multirow{2}{*}{ Sampling campaign } & \multirow{2}{*}{ Zone } & \multirow{2}{*}{$\mathrm{pH}$} & \multirow{2}{*}{$\begin{array}{c}E C_{w} \\
d S m^{-1}\end{array}$} & Ca & Mg & $\mathrm{Na}$ & $\mathbf{K}$ & $\mathrm{HCO}_{3}$ & $\mathrm{Cl}$ & $\mathrm{SO}_{4}$ \\
\hline & & & & \multicolumn{7}{|c|}{$\mathrm{mg} \mathrm{l}^{-1}$} \\
\hline \multirow{3}{*}{ Sep 2013} & I & 7.2 & 0.15 & 10.3 & 6.0 & 7.6 & 2.2 & 57.2 & 7.6 & 16.0 \\
\hline & II & 7.2 & 0.40 & 27.2 & 17.7 & 22.8 & 5.3 & 198.1 & 22.9 & 23.8 \\
\hline & III & 7.3 & 0.50 & 22.3 & 34.5 & 30.0 & 5.2 & 201.7 & 16.6 & 39.2 \\
\hline \multirow{3}{*}{ Jan 2014} & $\mathrm{I}$ & 6.5 & 0.09 & 15.1 & 3.4 & 6.8 & 1.6 & 31.7 & 3.8 & 12.3 \\
\hline & II & 7.0 & 0.20 & 21.0 & 4.3 & 17.2 & 3.4 & 55.1 & 10.2 & 14.2 \\
\hline & III & 7.1 & 0.34 & 39.0 & 6.4 & 27.1 & 2.8 & 111.5 & 13.1 & 27.7 \\
\hline \multirow{3}{*}{ Jul 2014} & 1 & 6.5 & 0.14 & 9.2 & 5.6 & 9.8 & 0.2 & 38.8 & 9.4 & 17.4 \\
\hline & II & 6.4 & 0.20 & 12.9 & 6.9 & 15.0 & 2.0 & 55.9 & 11.3 & 21.6 \\
\hline & III & 7.0 & 0.35 & 17.3 & 15.9 & 21.5 & 0.6 & 120.5 & 13.2 & 30.8 \\
\hline
\end{tabular}

Table 3. Pairwise comparison of p-value among sampling campaigns of the three zones for sugarcane, grape, and passion fruit under rainfall scenarios of 50 and $75 \%$ probabilities of exceedance

\begin{tabular}{|c|c|c|c|c|c|c|}
\hline \multirow{2}{*}{ Sampling campaigns } & \multicolumn{2}{|c|}{ Zone I } & \multicolumn{2}{c|}{ Zone II } & \multicolumn{2}{c|}{ Zone III } \\
\cline { 2 - 7 } & P50\% & P75\% & P50\% & P75\% & P50\% & P75\% \\
\hline Sept-2013 vs Jan-2014 & & & & & & \\
\cline { 1 - 3 } Sept-2013 vs Jul-2014 & \multirow{2}{*}{0.988} & 0.829 & 0.424 & 0.388 & 0.775 & 0.722 \\
\cline { 1 - 1 } Jan-2014 vs Jul-2014 & & & & & & \\
\hline
\end{tabular}

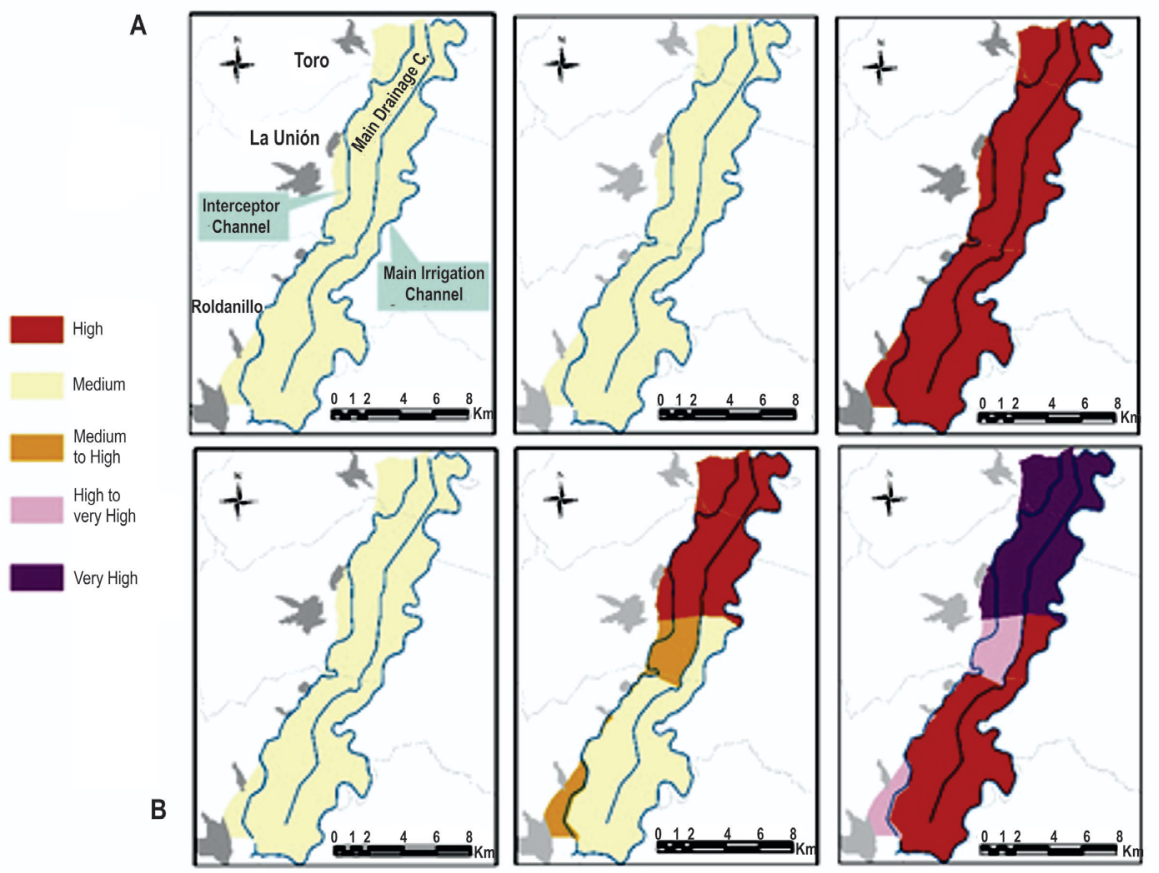

Figure 2. Spatial distribution of soil salinity risk. a) rainfall scenario of $50 \%$ probability of exceedance. b) rainfall scenario of $75 \%$ probability of exceedance 
grape and passion fruit had different soil salinity risk in the three zones, much higher in the northern zone (zone III) than the southern zone (zones I and II). The grape crop increased from medium soil salinity risk in zone I, passing by medium to high (LR values from 0 . to 0 .) in zone II, to high in zone III. Likewise, passion fruit crop rose from high soil salinity risk, falling into high to very high (LR values from 0. to 0.) in zone I, to very high (LR values from 0.11 to 0.20 ) in zone III.

\section{Discussion}

Under rainfall scenario of $50 \%$ probability of exceedance both sugarcane and grape fall in medium soil salinity risk. Statistical significances ( $p$-value<0.5) were found in the post-hoc analysis between these two crops and passion fruit (Table 4), which classed as a high category. Reducing the precipitation in 25\% (P75\%) the soil salinity risk in sugarcane keeps in medium; whereas, both grape and passion fruit raise one category in zone II, from medium to high, and from high to very high, respectively; and two categories in zone III, from medium to high, and from high to very high, respectively. Furthermore, the statistical significances (P-value $<0.05)$ remain between sugarcane and passion fruit, and between grape and passion fruit (Table 4).

Differences of soil salinity risk among crops and zones may be due to the crop salt tolerance, as well as the irrigation water quality-especially the ECw: the passion fruit is more sensitive than the grape and the sugarcane are; and the irrigation water quality in the zone III-where canals carry drained water and domestic wastewater-is poorer than the zones II and I where canals convey domestic wastewater and water from the Cauca river, respectively. Thus, these two parameters are the sensible inputs in the SOSALRIEGO approach. Peragón et al., (2016), found that ECw influenced highly when they assessed the soil salinity risk for an olive crop.

On the other hand, the climatological conditions on the area is a factor that can affect soil salinity, since this area is considerate dry, whose means the rainfall is low and evapotranspiration is high; therefore, the irrigation necessities increase, and the accumulation of salts as well, if we do not handle it very well. Despite the fact we assessed the soil salinity risk by employing SOSALRIEGO-GIS, the approach computes together hazard and vulnerability components, and this issue disallows tackling each component separately. Besides, other inputs such as fertilization, water table and irrigation method may affect the soil salinity risk as well. Masoudi et al., (2006) and Zhou et al., (2013) found that for evaluating the soil salinity risk inputs such as water table and organic fertilizers are essential.

\section{Conclusion}

In this paper the soil salinity risk in the RUT irrigation district for sugarcane, grape, and passion fruit was assessed by coupling SOSALRIEGO-GIS. For those crops with salt tolerance the risk level was lower. That is a medium soil salinity risk for sugarcane, a medium to high for grape, and a high to very high for passion fruit. Furthermore, the soil salinity risk was higher in zones with poor irrigation water quality. Zones II and III, which canals convey domestic wastewater and drained water fell in greater salinity risk category than zone I, which bears water withdrawal from the Cauca River.

SOSALRIEGO-GIS seemed a useful tool for assessing soil salinity risk as it allows identifying the risk on the surface. However, the approach computes together hazard and vulnerability components, and this issue disallows tacking each component separately. Besides, other inputs such as fertilization, water table and irrigation method may affect the soil salinity risk as well.

\section{Acknowledgements}

Authors would like to thank ASORUT, and REGAR research group-Universidad del Valle for supporting and funding the research study. In addition, we would like to extend our gratitude to COLCIENCIAS for supporting

Table 4. Pairwise comparison of $p$-value among sugarcane, grape, and passion fruit in the three zones for under rainfall scenarios of 50 and $75 \%$ probabilities of exceedance

\begin{tabular}{|c|c|c|c|c|c|c|}
\hline \multirow{2}{*}{ Crops } & \multicolumn{2}{|c|}{ Sept-2013 } & \multicolumn{2}{|c|}{ Jan-2014 } & \multicolumn{2}{|c|}{ Jul-2014 } \\
\hline & P50\% & P75\% & P50\% & P75\% & P50\% & P75\% \\
\hline Sugarcane vs Grape & 0.270 & 0.360 & 0.087 & 0.160 & 0.040 & 0.039 \\
\hline Sugarcane vs Passion fruit & 0.000 & 0.000 & 0.000 & 0.000 & 0.000 & 0.000 \\
\hline Grape vs Passion fruit & 0.008 & 0.007 & 0.017 & 0.011 & 0.026 & 0.028 \\
\hline
\end{tabular}


us by means of calls PhD. national (CV 528-2012) and young researcher (CV 723-2012).

\section{References}

Akramkhanov A, Martius C, Park SJ, Hendrickx JMH. Environmental factors of spatial distribution of soil salinity on flat irrigated terrain. Geoderma. 2011;163:55-62.

APHA, Standard Methods for the Examination of Water and Wastewater, 20th ed. (Amer Public Health Assn, Washington, DC, 1999).

Ayers R, Westcot D. 1985. Water quality for agriculture. FAO. Irrigation and Drainage Paper 29. Rev. 1. Rome, Italy

Bargaouni Z, Chebbi A. Comparison of Two Kriging Interpolation Methods Applied to Spatiotemporal Rainfall. Journal of Hydrology. 2009;365(1-2):56-73.

Bouksila F, Bahri A, Berndtsson R, Persson M, Rozema J, Van der Zeef $\mathrm{S}$. Assessment of soil salinization risks under irrigation with brackish water in semiarid Tunisia. Environmental and Experimental Botany. 2013;92:176-185.

Bostan P, Heuvelink G, Akyurek S. Comparison of Regression and Kriging Techniques for Mapping the Average Annual Precipitation of Turkey. Int J Appl Earth Obs Geoinf. 2012;19(1):115-26.

Clermont-Dauphin C, Suwannang N, Grünberger O, Hammecker C, Maeght JL. Yield of rice under water and soil salinity risks in farmers' fields in northeast Thailand. F Crop Res. 2010;118:289296.

Di Piazza A, Lo Conti F, Noto L, Viola F, La Loggia G. Comparative Analysis of Different Techniques for Spatial Interpolation of Rainfall Data to Create a Serially Complete Monthly Time Series of Precipitation for Sicily, Italy. Int J Appl Earth Obs Geoinf. 2011;13(3):396-408.

De Paz JM, Visconti F, Zapata R, Sánchez J. Integration of two simple models in a geographical information system to evaluate salinization risk in irrigated land of the Valencian Community, Spain. Soil Use Manag. 2004;20:333-342.

De Paz J, Visconti F, Molina M. 2007. Metodología para la elaboración de un mapa de riesgo de salinización del suelo en la Comunidad Valenciana, in: III Simposio

FAO. 2007. Water at a glance. The relationship between water, agriculture, food security and poverty. Recurso electrónico disponible en: http://www.fao.org/nr/water/art/2007/glance/index. html.

Fernández A, Villafañe R, Hernandez R. Calidad del agua de riego y afectación de los suelos por sales en la península de Paraguaná, Venezuela. Agronomía Trop. 2011;61 (3-4):253-265.
García Álvaro. 2013. Manejo de la degradación del suelo. En: Ciencia del suelo. Principios básicos. Sociedad Colombina de la Ciencia del Suelo. Bogotá, Colombia. P. 304-356.

IGAC- CVC. 2004. Levantamiento de suelos y zonificación de tierras del Departamento del Valle del Cauca. Bogotá D.C. Colombia. $775 \mathrm{p}$.

Juan P, Mateu J, Jordan MM, Mataix-Solera J, Meléndez-Pastor I, Navarro-Pedreño J. Geostatistical methods to identify and map spatial variations of soil salinity. J. Geochemical Explor. 2011;108:62-72.

Kanzari S, Hachicha M, Bouhlila R, Battle-Sales J. Characterization and modeling of water movement and salts transfer in a semiarid region of Tunisia (Bou Hajla, Kairouan) - Salinization risk of soils and aquifers. Comput Electron Agric. 2012;86:34-42.

Masoudi M, Patwardhan A, Gore S. A new methodology for producing of risk maps of soil salinity, Case study: Payab Basin, Iran. J. Appl. Sci. Environ. Manag. 2006;10:9-13.

Mirlas V. Assessing soil salinity hazard in cultivated areas using MODFLOW model and GIS tools: a case study from the Jezre'el Valley, Israel. Agric Water Manage. 2012;109:144-154.

Peragón Juan Manuel, Delgado Antonio, Rodríguez Díaz Juan Antonio, Pérez-Latorre Francisco J. A GIS-based decision tool for reducing salinization risks in olive orchards. Agr Water Manage. 2016;166:33-41.

Triantafilis J, Odeh IO, Warr B, Ahmed MF. Mapping of salinity risk in the lower Namoi valley using non-linear kriging methods. Agr Water Manage. 2004;69:203-231.

Urrutia N. 2006. Sustainable management after irrigation system transfer. Experiences in Colombia. The RUT Irrigation District. PhD Dissertation. Delft, Netherlands. 312 p.

USDA-UNITED STATE DEPARTMENT OF AGRICULTURAL. 1954 Diagnosis and improvements of saline and alkali soils. Agriculture handbook № 60, United States Department of Agriculture, Washington, D.C. 159 p.

Utset A, Borroto M. A modeling-GIS approach for assessing irrigation effects on soil salinisation under global warming conditions. Agricultural Water Managment. 2001;50: 53-63.

Villafañe R. Sosalriego: un procedimiento para diagnosticar los riesgos de sodificación y salinización del suelo con el agua de riego (nota técnica). Bioagro. 2011;23:57-64.

Zhou D, Lin Z, Liu L, Zimmermann D. Assessing secondary soil salinization risk based on the PSR sustainability framework. J Environ Manage. 2013;128: 642-65. 